www.jmscr.igmpublication.org

Impact Factor (SJIF): 6.379

Index Copernicus Value: 71.58

ISSN (e)-2347-176x ISSN (p) 2455-0450

crossref DOI: https://dx.doi.org/10.18535/jmscr/v6i4.148

Journal Of Medical Science And Clinical Research

IGM Publication

An official Publication of IGM Publication

\title{
The Effectiveness of Insect Growth Regulator (IGR) on the Growth and the Development of Aedes aegypti and Aedes albopictus in Tangerang City, Indonesia
}

\author{
Authors
Cecep Dani Sucipto ${ }^{1 *}$, Didin Wahyudin², Heri Jati Santoso ${ }^{3}$, Itha Latho ${ }^{4}$, Asep Tata Gunawan 5 \\ ${ }^{1,2}$ Minister of Health Polytechnic, Banten, Indonesia
}

${ }^{3}$ Board for Development and Empowerment of Health Human Resource, Ministry of Health Republic Indonesia

${ }^{4}$ Institute of Health Science Masda, Pamulang University, Indonesia,

${ }^{5}$ Minister of Health Polytechnic, Semarang, Indonesia

*Corresponding Author

Cecep Dani Sucipto

Minister of Health Polytechnic, Banten, Indonesia

Email: suciptocecepdani@gmail.com

\begin{abstract}
Background: Dengue fever is a world health problem. It is endemic in more than 100 countries and threatens about 2.5 billion or $40 \%$ of people living in urban, suburban, and rural areas in both tropical and subtropical climates. Various mitigation measures have been undertaken, including vector control using mosquito nest eradication, selective abatization with larvicides, and mosquito fogging. Elimination using chemicals causes many problems. Another alternative to control the growth and development of Aedes sp. mosquito is needed. The use of insect growth regulator (IGR) is suggested to overcome this problem, since it does not affect the cleanliness of water, does not increase resistance, and considered safe.

The Objective: The objective of this research was the $I E_{50}, I E_{90}$, and $L C_{50}$ concentration of pyriproxyfen to eliminate Aedes aegypti and Aedes albopictus larvae.

Method: The type of research used was laboratory experimental with a post-test design with only one group control design. This research was done through the actual test by creating dose variations of 1000 ppm of pyriproxyfen, which were as much as $0,14 \mathrm{~mL} ; 0.196 \mathrm{~mL} ; 0.274 \mathrm{~mL} ; 0.384 \mathrm{~mL} ; 0.538 \mathrm{~mL}$; and $0.752 \mathrm{~mL}$. The results of observation of larvae mortality were calculated by probit analysis to obtain the $L C_{50}$ value of pyriproxyfen against Aedes aegypti and Aedes albopictus. The $L C_{50}$ value obtained from probit calculation was replicated four times and used to find the value of $L T_{50}$.

Results: Aedes aegypti and Aedes albopictus larvae after pyriproxyfen treatment and probit calculation showed inhibition of the growth Aedes aegypti larvae, indicated by $I E_{50}$ value (95\% Fiducial limits (FL)) of 0.17ppb (0.13$0.21)$ and $I E_{90}(95 \% \mathrm{FL})$ of 0.68ppb (0.43-1.08). Inhibition of the growth of Aedes albopictus larvae was indicated by the value of $I E_{50}(95 \% \mathrm{FL})$ of $0.11 \mathrm{ppb}(0.09-0.13)$ and $I E_{90}(95 \% \mathrm{FL})$ of $0.39 \mathrm{ppb}$ (0.26-0.57). External morphological changes also occurred to Aedes aegypti and Aedes albopictus larvae after the exposure. Flaking of the cuticle to the thorax and swelling of both the head and the thorax were observed. Therefore, insect growth regulator has the potential to prevent the development of larvae into adult mosquitoes.

Conclusions: Pyriproxyfen can inhibit the growth of larvae. Pyriproxyfen $L C_{50}$ concentration on Aedes aegypti larvae were $1.63 \mathrm{ppm}$ and on Aedes albopictus larvae was 1.56ppm. The use of pyriproxyfen causes external morphological changes to occur in larvae, pupae, and adult mosquitoes especially on the feet, whereas the proboscis and wings do not undergo morphological changes.

Keywords: Aedes aegypti, Aedes albopictus, Insect Growth Regulator (IGR), Larvae, Pyriproxyfen.
\end{abstract}




\section{Introduction}

Dengue fever is a world health problem. It is endemic in more than 100 countries and threatens about 2.5 billion or $40 \%$ of people living in urban, suburban, and rural tropical and subtropical climates. As of May 2007, dengue fever cases in Indonesia reached 66,365 people with 738 deaths (Kusriastuti, 2007). Various mitigation measures have been undertaken, including vector control utilizing mosquito nest eradication, selective abatization with larvicides, mosquito fogging. In addition to vector control, other efforts were made such as the detection and early treatment of dengue cases (Dinkes Kota Tangerang, 2015).

The primary vector of dengue fever is Aedes aegypti, while its secondary vector is Aedes albopictus (Djakaria, 1998). According to Sutomo (2003), the vector of dengue fever always lives near residential areas where living conditions and sanitation are inadequate. In Thailand, according to Ponlawat et al. (2005), Aedes albopictus is more challenging to control than Aedes aegypti because of its more comprehensive range of habitats, found mostly in suburban and rural areas, and in open areas overgrown with plants. Aedes albopictus in Thailand has been poorly resistant to temefos, malathion, and permethrin.

Eradication of mosquitoes by using chemicals causes problems such as increased resistance, environmental pollution, poisoning, and nontarget animal deaths. Given the constraints in the use of insecticides, another option to control Aedes sp. larvae is needed. The method of insect growth regulator (IGR) is suggested to overcome this problem because it does not affect water cleanliness, does not increase resistance, and it is safe (Munif, 1997). Insecticides used to control the Aedes sp. species in water reservoirs should have low toxicity to mammals (WHO, 1995).

Pyriproxyfen is used to control mosquito populations in residential areas, as vector control programs, and as well as to monitor mosquito in husbandry areas. Pyriproxyfen is effective at low doses, low toxicity to mammals, and relatively safe to the environment (Wirawan, 2006). The results of the study of Ali et al. (1995) obtained the results that pyriproxyfen $\left(\mathrm{LC}_{90}=0.000376\right.$ ppm) is more toxic 2.23 and 21.5 times compared to diflubenzuron and methoprene. Waris research (2005) about the influence of pyriproxyfen on malaria vector Anopheles subpictus grassi showed that there was an abnormality causing mortality in the adult mosquito (larvae and pupae).

Pyriproxyfen has never been applied to dengue fever vectors in Tangerang City. If pyriproxyfen will be used as a means of controlling the dengue fever vector, it is necessary to know the diagnostic concentration for monitoring the mosquito susceptibility in the field. For that purpose, laboratory scale research of the effectiveness of the usage of insect growth regulator (IGR) pyriproxyfen on the growth and the development of Aedes aegypti and Aedes albopictus larvae in Tangerang City, Indonesia was done with the aim to know the inhibitory power ( $\mathrm{IE}_{50}$ and $\left.\mathrm{IE}_{90}\right)$ and $\mathrm{LC}_{50}$ concentration of pyriproxyfen to Aedes aegypti and Aedes albopictus larvae.

\section{Materials and Methods}

The type of research used was laboratory experimental with a post-test design with only one group control design. The subjects were divided into two groups: treatment group and control group. The subjects used were third instar larvae from three sub-district in Tangerang City by installing more than 100 house traps in 100 houses, both inside and outside the home. Determination of the location was based on the endemicity of the region and data on the incidence of dengue cases in recent months.

The treatment was initiated by conducting the preliminary test to determine the variation of $\mathrm{LC}_{50}$ concentration. The pyriproxyfen solution for the preliminary test was prepared as follows: $10 \mathrm{~g}$ Sumilarv $0.5 \% \quad(\mathrm{w} / \mathrm{w})$ with active ingredient pyriproxyfen was dissolved in acetone up to 50 $\mathrm{mL}$ volume (1000ppm active ingredient). The concentration variations were made by introducing a $0.1 \mathrm{ml} ; 0.2 \mathrm{ml} ; 0.3 \mathrm{ml} ; 0.4 \mathrm{ml} ; 0,5 \mathrm{ml}$; $0.6 \mathrm{ml}$; and $0.7 \mathrm{ml}$ pyriproxyfen solution into a test 
container containing tap water and 25 instars larvae to obtain the final volume of $200 \mathrm{~mL}$, thus the concentration variations of $0.5 \mathrm{ppm} ; 1.0 \mathrm{ppm}$; $1.5 \mathrm{ppm} ; 2.0 \mathrm{ppm} ; 2.5 \mathrm{ppm} ; 3.0 \mathrm{ppm}$ and $3.5 \mathrm{ppm}$ were obtained. Observations were made 48 hours after the treatment, and the percentage of larval mortality between $10 \%$ to $95 \%$ was used as a reference to determine the concentration variation in the actual test by using increment factor. The concentration for larvae mortality test was calculated by increment factor with 6 variations of concentration, i.e. $0.70 \mathrm{ppm} ; 0.98 \mathrm{ppm} ; 1.37 \mathrm{ppm}$; 1.92ppm; 2.69ppm; and 3.76ppm.

The actual test was performed by varying the concentration of $1000 \mathrm{ppm}$ of pyriproxyfen by adding as much as $0.14 \mathrm{ml} ; 0.196 \mathrm{ml} ; 0.274 \mathrm{ml}$; $0.384 \mathrm{ml} ; 0.538 \mathrm{ml}$; and $0.752 \mathrm{ml}$ into each test container containing tap water and 25 larvae and fixed to $200 \mathrm{~mL}$ volume. The first controls contained 25 larvae in the mixture of $200 \mathrm{~mL}$ water and $0.752 \mathrm{~mL}$ acetone and the second one included 25 larvae in $200 \mathrm{~mL}$ water. Each treatment was made four replications. Observation of larvae mortality was performed 48 hours after the exposure. The results of inspection of larvae mortality were calculated by probit analysis to obtain the $\mathrm{LC}_{50}$ value of pyriproxyfen against Aedes aegypti and Aedes albopictus.

The $\mathrm{LC}_{50}$ value obtained from probit calculation was replicated four times and used to find the value of $\mathrm{LT}_{50}$. The preparation of the stock pyriproxyfen solution was the same as the preliminary test, while the volume addition depends on the $\mathrm{LC}_{50}$ value. Observations of larvae and pupae deaths were performed every 24 hours. The probit analysis was used to obtain the $\mathrm{LT}_{50}$ on Aedes aegypti and Aedes albopictus.

\section{Results}

Preliminary test results of pyriproxyfen inhibition to the growth and development of third instar larvae at each concentration showed that the pyriproxyfen concentration of $0.05 \mathrm{ppb}-0.4 \mathrm{ppb}$ caused $8 \%-84 \%$ inhibition on the growth of third instar larvae of Aedes aegypti and 16\%-92\% inhibition on the growth of third instar larvae of Aedes albopictus. The higher concentration showed the stronger inhibitory effect.

Preliminary test results at the recommended dose of $10 \mathrm{ppb}$; $30 \mathrm{ppb}$; and $50 \mathrm{ppb}$ showed that no larvae were successful in maturity, so they were not used in the actual test. The variations of concentration were calculated by increment factor and yielded $0.03 \mathrm{ppb} ; 0.05 \mathrm{ppb} ; 0.08 \mathrm{ppb} ; 0.14 \mathrm{ppb}$; $0.23 \mathrm{ppb} ; 0.39 \mathrm{ppb}$; and $0.67 \mathrm{ppb}$ as the concentration used in the actual test. The actual test used third instar larvae with 25 subjects in each treatment and replicated four times so that the total test larvae were 100 subjects in each treatment. The time required for the actual test was nine days at a temperature between $20^{\circ} \mathrm{C}$ $28^{\circ} \mathrm{C}$ and humidity between $51 \%-60 \%$.

On the first day of observation, Aedes aegypti larvae had entered the third and fourth instar stage. On day 2, it had started to occur 20\%-29\% reduction in the number of larvae after partially become pupa. On day 3 of observation, there was some decrease in the number of larvae in each treatment and control, which were varied between 48\%-64\%. On the 9th day, there was a decrease up to $100 \%$ because the larvae had become pupae and adult mosquito. Percentage of the number of pupae per day of observation can be seen in Figure 1 and percentage of the number of adult mosquito can be seen in Figure 2. 


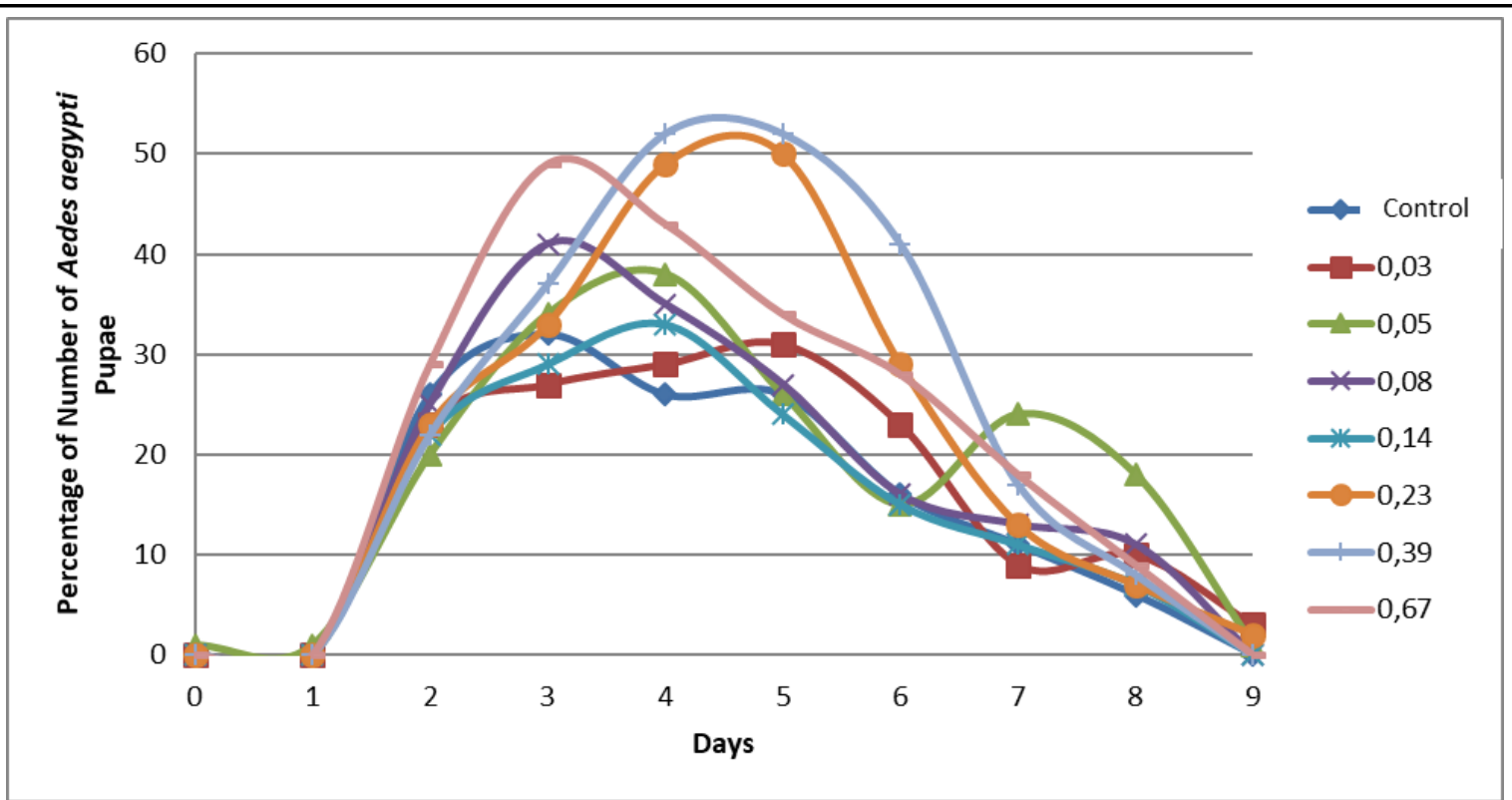

Figure 1 Percentage of number of Aedes aegypti pupae on the pyriproxyfen exposure of various concentrations and controls in units of time (days)

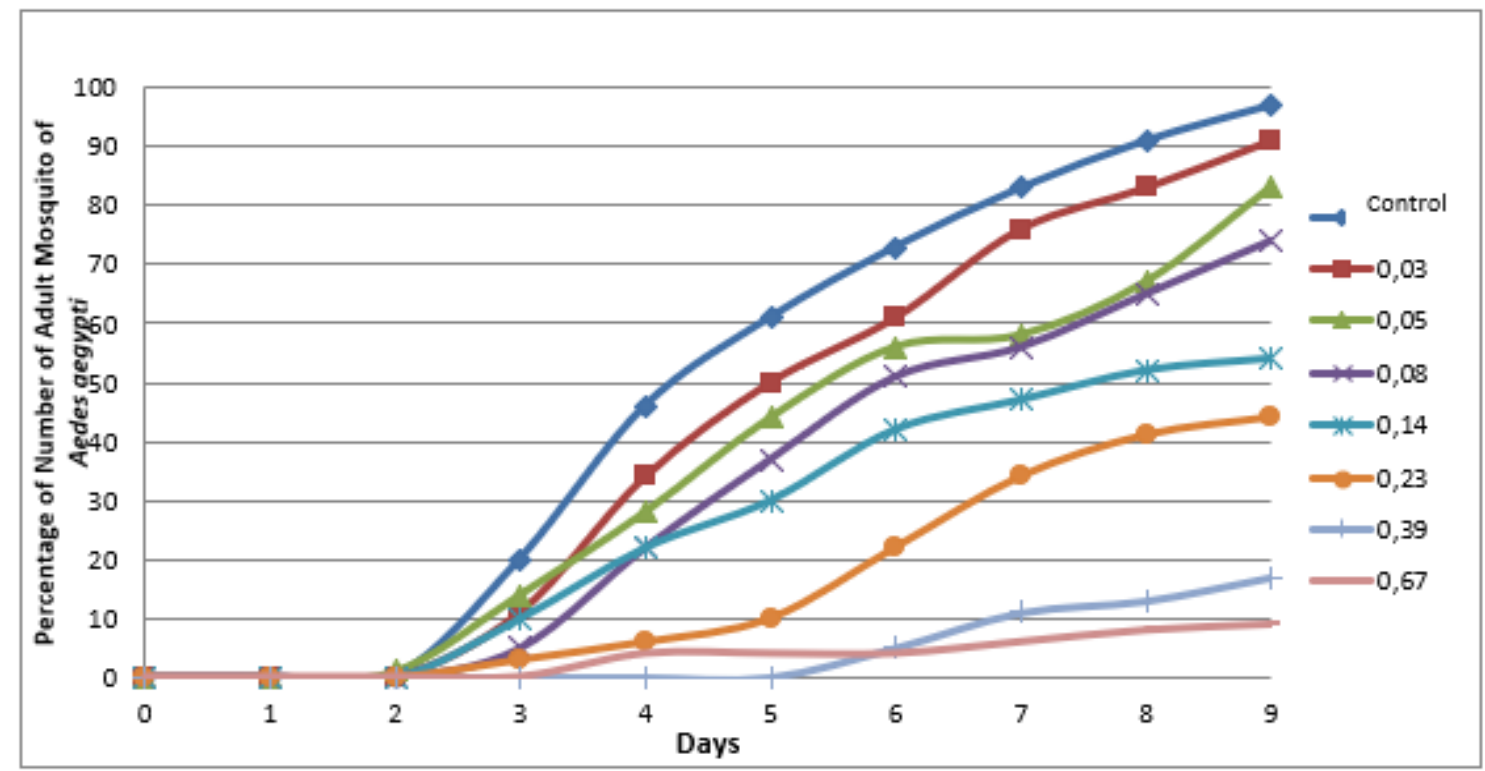

Figure 2 Percentage of number of Adult Mosquito of Aedes aegypti on the pyriproxyfen exposure of various concentrations and controls in units of time (days)

On the first day of observation, Aedes albopictus larvae have entered the third and fourth in star stage. On day 2, it had started to occur $68 \%-90 \%$ reduction in the number of larvae after partially become pupa. On day 3 of observation, there was some decrease in the number of larvae in each treatment and control, which were varied between
44\%-68\%. On the 9th day, there was a decrease up to $100 \%$ because the larvae had become pupae and adult mosquito. Percentage of the number of pupae per day of observation can be seen in Figure 3 and percentage of the number of adult mosquito can be seen in Figure 4. 


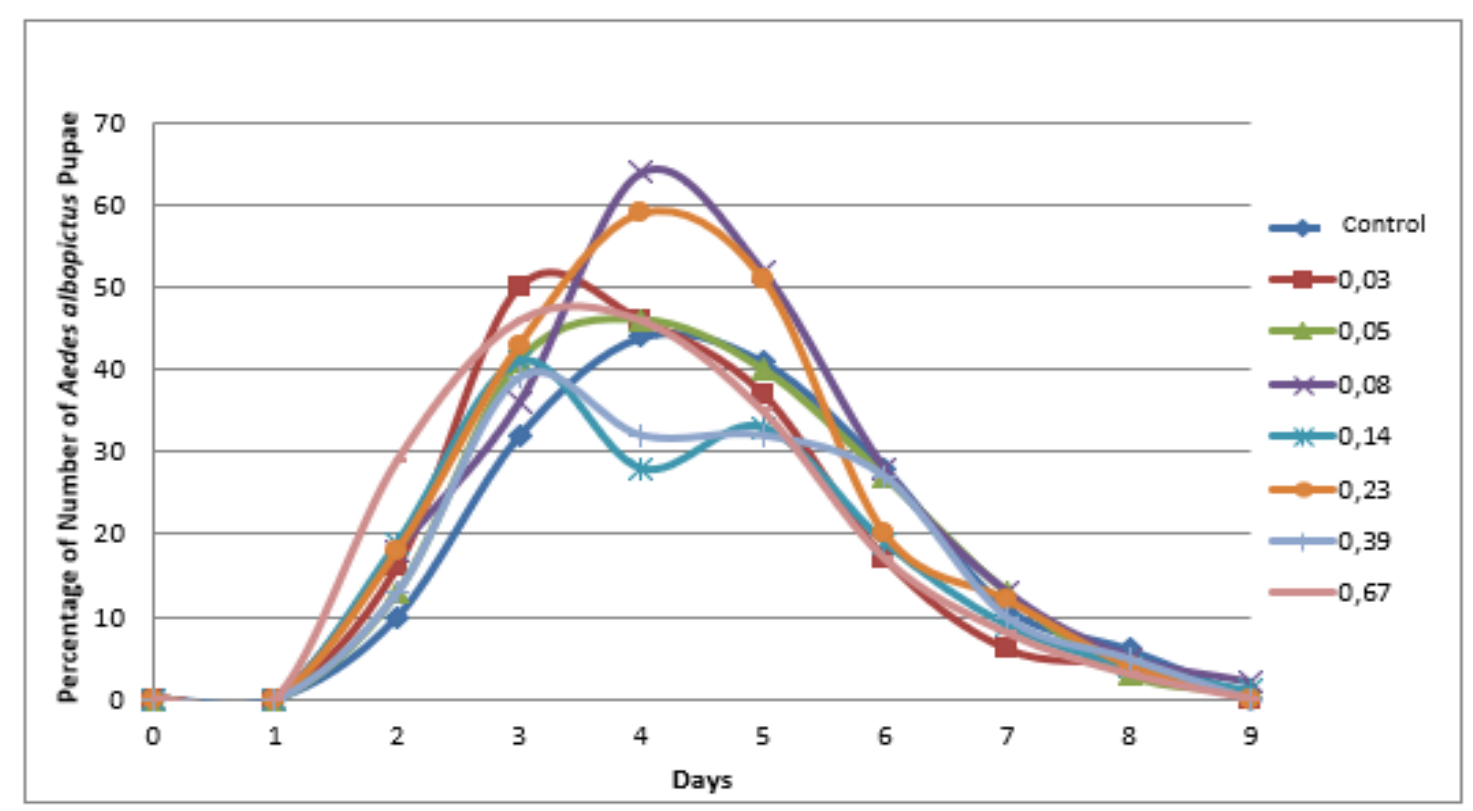

Figure 3. Percentage of number of Aedes albopictus pupae on the pyriproxyfen exposure of various concentrations and controls in units of time (days)

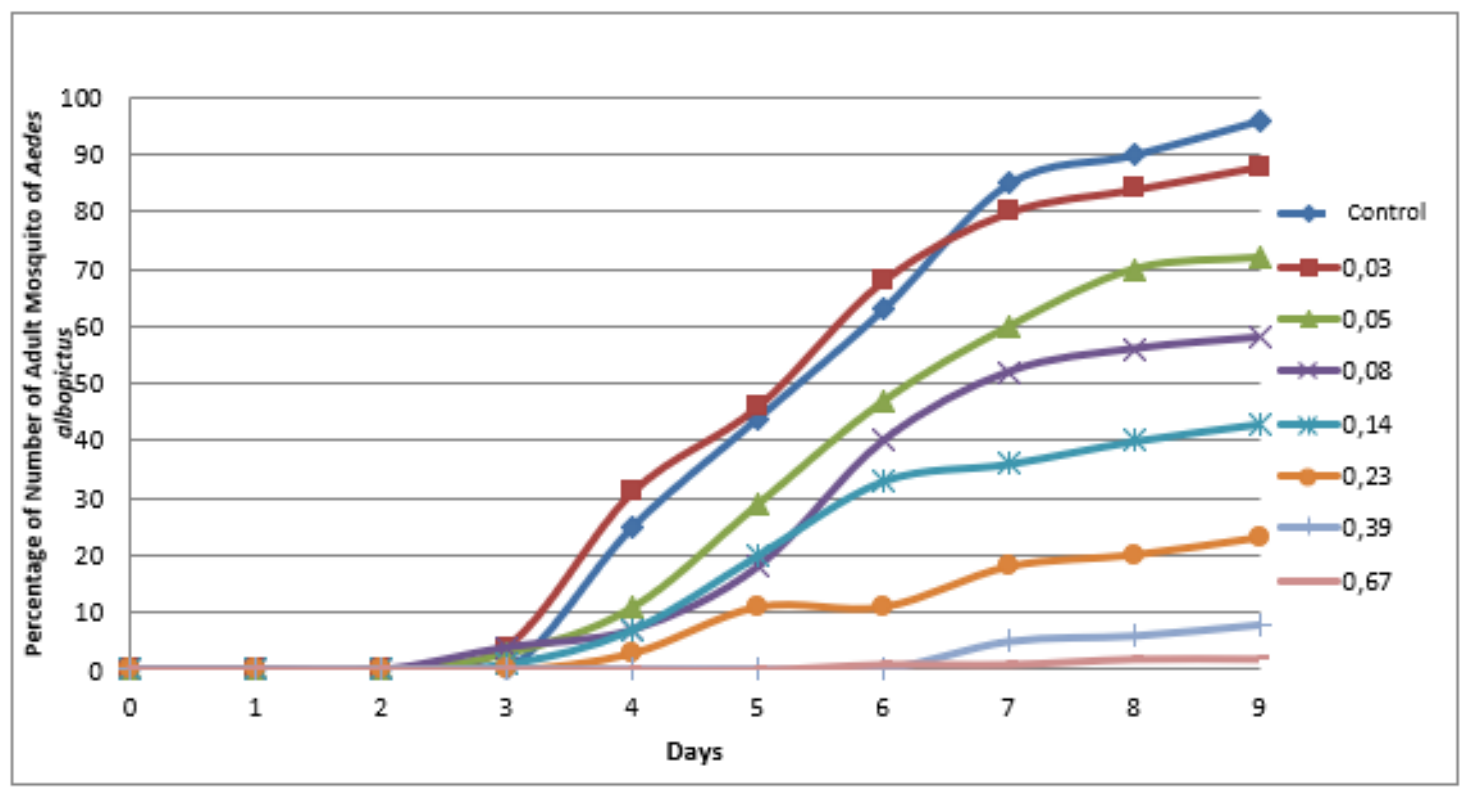

Figure 4. Percentage of number of Adult Mosquito of Aedes albopictus on the pyriproxyfen exposure of various concentrations and controls in units of time (days)

The observation of the development of Aedes aegypti and Aedes albopictus after pyriproxyfen treatment and probit calculation resulted that $\mathrm{IE}_{50}$ value (95\% Fiducial limits (FL)) for Aedes aegypti was $0.17 \mathrm{ppb}(0.13-0.21)$ and $\mathrm{IE}_{90}(95 \% \mathrm{FL})$ was
$0.68 \mathrm{ppb}(0.43-1.08) . \mathrm{IE}_{50}(95 \% \mathrm{FL})$ for Aedes albopictus was $0.11 \mathrm{ppb}(0.09-0.13)$ and $\mathrm{IE}_{90}(95 \%$ FL) was $0.39 \mathrm{ppb}(0.26-0.57)$. Inhibitory data on various concentration variations and the result of probit analysis are summarized in Table 1. 
Table $1 \mathrm{IE}_{50}$ and $\mathrm{IE}_{90}$ value of pyriproxyfen to third instar larvae of Aedes aegypti and Aedes albopictus after nine days of observation

\begin{tabular}{|c|c|c|c|c|c|c|c|c|}
\hline \multirow{2}{*}{ No } & \multirow{2}{*}{$\begin{array}{c}\text { Concentrat } \\
\text { ion } \\
(\mathrm{ppb})\end{array}$} & \multirow{2}{*}{$\begin{array}{l}\text { Number of } \\
\text { Samples }\end{array}$} & \multicolumn{3}{|c|}{$\begin{array}{c}\text { Aedes } \\
\text { aegypti }(\mathrm{n}=800)\end{array}$} & \multicolumn{3}{|c|}{ Aedes albopictus $(\mathrm{n}=800)$} \\
\hline & & & $\%$ IE & $\begin{array}{c}\mathrm{IE}_{50} \\
(95 \% \mathrm{FL})\end{array}$ & $\begin{array}{c}\mathrm{IE}_{90} \\
(95 \% \mathrm{FL})\end{array}$ & $\% \mathrm{IE}$ & $\begin{array}{c}\mathrm{IE}_{50} \\
(95 \% \mathrm{FL})\end{array}$ & $\begin{array}{c}\mathrm{IE}_{90} \\
(95 \% \mathrm{FL})\end{array}$ \\
\hline 1 & Control & 25 & 0,00 & & & 0,00 & & \\
\hline 2 & 0,03 & 25 & 6,19 & & & 8,33 & & \\
\hline 3 & 0,05 & 25 & 14,43 & & & 25,00 & & \\
\hline 4 & 0,08 & 25 & 23,71 & $0,17 \mathrm{ppb}$ & $0,68 \mathrm{ppb}$ & 39,58 & $0,11 \mathrm{ppb}$ & $0,39 \mathrm{ppb}$ \\
\hline 5 & 0,14 & 25 & 44,33 & $(0,13-0,21)$ & $(0,43-1,08)$ & 55,21 & $(0,09-0,13)$ & $(0,26-0,57)$ \\
\hline 6 & 0,23 & 25 & 54,64 & & & 76,04 & & \\
\hline 7 & 0,39 & 25 & 82,47 & & & 91,67 & & \\
\hline 8 & 0,67 & 25 & 90,72 & & & 97,92 & & \\
\hline
\end{tabular}

Preliminary test with pyriproxyfen treatment for the exposure of 48 hours showed the percentage of the death of Aedes aegypti at the lowest concentration $(0,5 \mathrm{ppm})$ was equal to $8 \%$ and at the highest level $(3,5 \mathrm{ppm})$ was equal to $84 \%$. The preliminary test of Aedes albopictus showed the percentage of death over 48 hours exposure was similar to of $12 \%$ at the lowest concentration $(0.5 \mathrm{ppm})$ and $88 \%$ at the highest level (3.5ppm) as shown in Table 2.

Table 2. Mortality percentage of third instar larvae of Aedes aegypti and Aedes albopictus after 48 hours of exposure to pyriproxyfen in various concentration for the preliminary test

\begin{tabular}{lccccc}
\hline \multirow{2}{*}{$\begin{array}{l}\text { Concentration } \\
(\mathrm{ppm})\end{array}$} & \multirow{2}{*}{$\begin{array}{c}\text { Number of } \\
\text { Samples }\end{array}$} & $\begin{array}{c}\text { No. of Death } \\
\text { Larvae }\end{array}$ & $\begin{array}{c}\text { Percentage } \\
(\%)\end{array}$ & $\begin{array}{c}\text { No. of Death } \\
\text { Larvae }\end{array}$ & $\begin{array}{c}\text { Percentage } \\
(\%)\end{array}$ \\
\hline Control & 25 & 0 & 0 & 0 & 0 \\
0,5 & 25 & 2 & 8 & 3 & 12 \\
1,0 & 25 & 4 & 16 & 5 & 20 \\
1,5 & 25 & 10 & 40 & 8 & 32 \\
2,0 & 25 & 14 & 56 & 15 & 60 \\
2,5 & 25 & 17 & 68 & 18 & 84 \\
3,0 & 25 & 20 & 80 & 21 & 88 \\
3,5 & 25 & 21 & 84 & 22 & \\
\hline
\end{tabular}

Effect of concentration variations on Aedes aegypti and Aedes albopictus larvae resulted in the larvae mortality value that was not much different so that the concentration variations for two species were similar. Variations of concentration to be used to determine $\mathrm{LC}_{50}$ value were based on the results of the calculation of 6 variations, which were: $0.70 \mathrm{ppm} ; 0.98 \mathrm{ppm} ; 1.37 \mathrm{ppm} ; 1.92 \mathrm{ppm}$;

Table $3 \mathrm{LC}_{50}$ value of pyriproxyfen to third instar larvae of Aedes aegypti and Aedes albopictus after 48 hours of exposure

\begin{tabular}{|c|c|c|c|c|c|c|}
\hline \multirow[b]{2}{*}{ No } & \multirow[b]{2}{*}{$\begin{array}{l}\text { Concentration } \\
\text { (ppm) }\end{array}$} & \multirow[b]{2}{*}{$\begin{array}{l}\text { Number of } \\
\text { Sample }\end{array}$} & \multicolumn{2}{|c|}{ Aedes aegypti $(\mathrm{n}=700)$} & \multicolumn{2}{|c|}{ Aedes albopictus $(\mathrm{n}=700)$} \\
\hline & & & $\begin{array}{c}\text { Death } \\
\text { Percentage } \\
(\%)\end{array}$ & $\begin{array}{c}\mathrm{LC}_{50} \\
(95 \% \mathrm{FL})\end{array}$ & $\begin{array}{c}\text { Death } \\
\text { Percentage } \\
(\%)\end{array}$ & $\begin{array}{c}\mathrm{LC}_{50} \\
(95 \% \mathrm{FL})\end{array}$ \\
\hline 1 & Control & 25 & 0 & & 1 & \\
\hline 2 & 0,70 & 25 & 12 & & 14 & \\
\hline 3 & 0,98 & 25 & 25 & & 25 & \\
\hline 4 & 1,37 & 25 & 40 & $1,63 \mathrm{ppm}$ & 37 & $1,56 \mathrm{ppm}$ \\
\hline 5 & 1,92 & 25 & 54 & & 56 & \\
\hline 6 & 2,69 & 25 & 76 & & 84 & \\
\hline 7 & 3,76 & 25 & 92 & & 95 & \\
\hline
\end{tabular}


Morphological changes after the treatment of pyriproxyfen were documented. There were noticeable differences between Aedes aegypti and Aedes albopictus larvae which were dead without

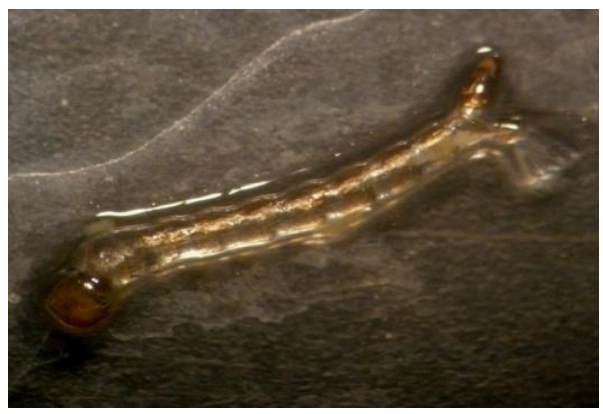

a. Aedes aegypti larvae

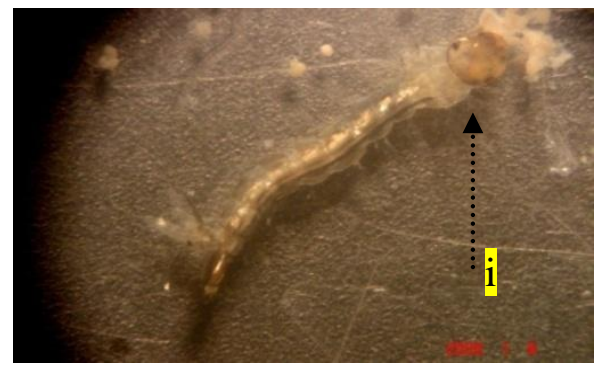

c. Aedes aegypti larvae

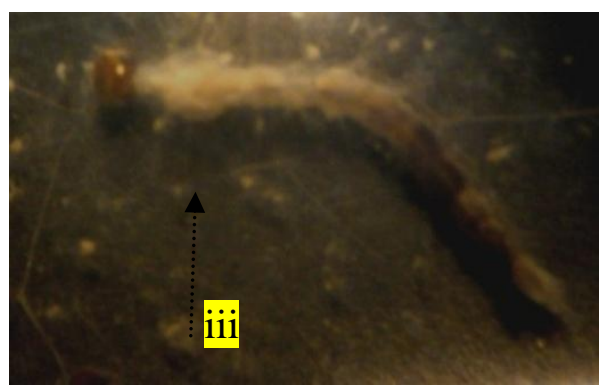

e. Aedes aegypti larvae exposure to pyriproxyfen (controls) and those which were exposed to pyriproxyfen. Figure 5 showed the morphological changes of larvae.

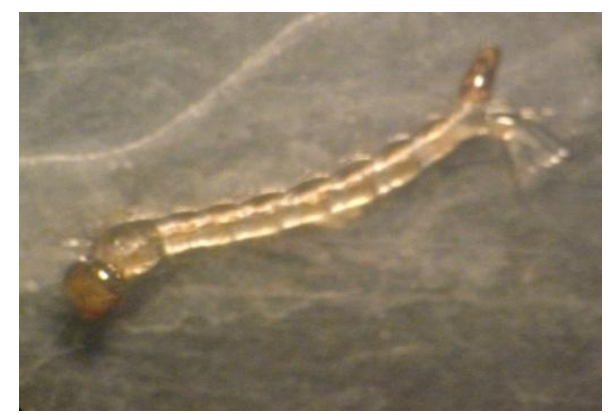

b. Aedes albopictus larvae

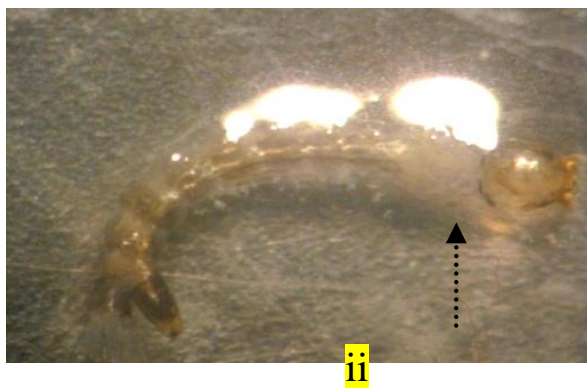

d. Aedes albopictus larvae

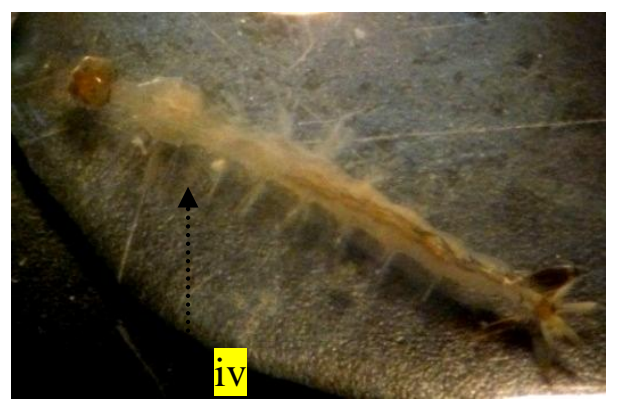

f. Aedes albopictus larvae

Figure 5. a-b. Dead controls larvae

c-f. Dead larvae after 48 hours exposure to pyriproxyfen

i. cuticle detached from the thorax and fluid come out from the head

ii. cuticle disconnected from the thorax and the head swell

iii. thorax and abdomen damage on segment 1-4

iv. thorax damage and abdomen turned into white-colored

Aedes aegypti and Aedes albopictus pupae exposed to pyriproxyfen gave varying results. In the inhibition test, some of the dead pupae suffered damage to the first and second segment abdomen as shown in Figure 6.c and its entrails came out (Figure 6.d). As a comparison, dead pupae which were not exposed to pyriproxyfen (controls) is shown in Fig. 6.a-b. 


\section{JMSCR Vol||06||Issue ||04||Page 890-902||April}

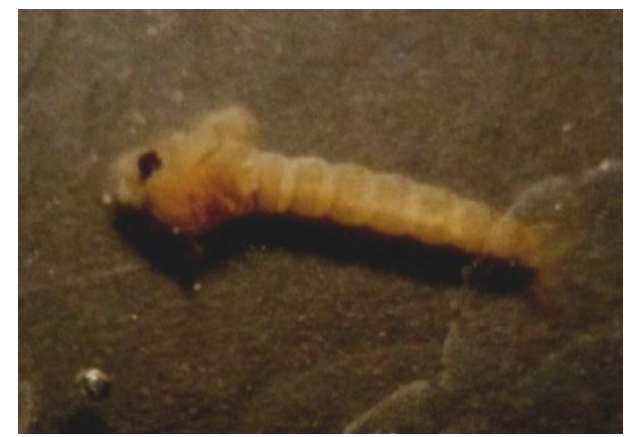

a. Aedes aegypti Pupae

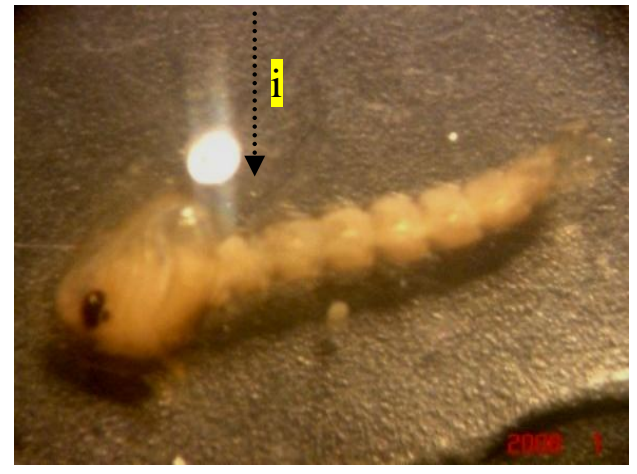

c. Aedes aegypti Pupae

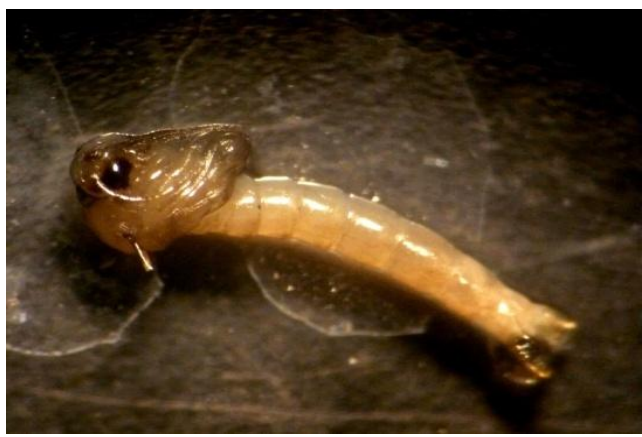

b. Aedes albopictus Pupae

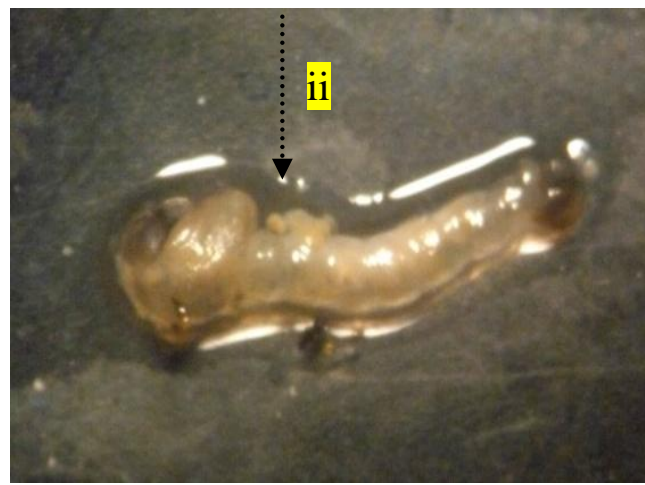

d. Aedes albopictus Pupae

Figure 6. a-b. Dead controls pupae

c-d. Dead pupae treated with pyriproxyfen

i. The body part was damaged in the first and second segment abdomen

ii. Some of the entrails came out from the second abdomen

The results of inhibition tests showed that some mosquitoes could successfully become adults. Observations were made to its legs, probes, and wings. Some of Aedes aegypti and Aedes albopictus pupae did not succeed to become perfect adult mosquito because the adult mosquitoes could not get out of the pupal case as shown in Figure 7.a-f. Most occurred in the legs that could not be separated from the pupal case, but there was also a wing section that could not get out of the pupal case.

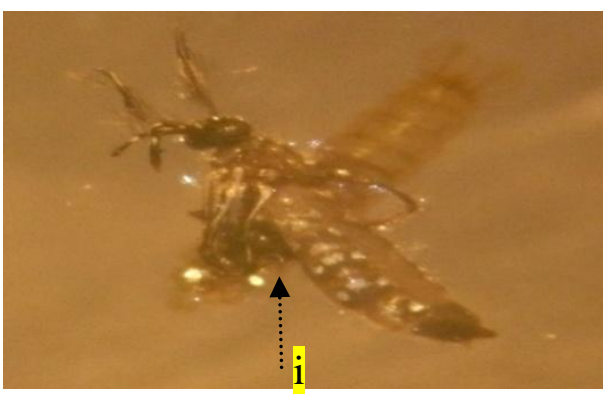

a. Aedes aegypti Mosquito

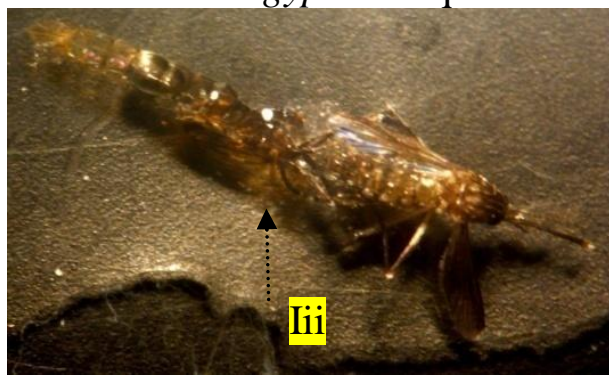

c. Aedes aegypti Mosquito

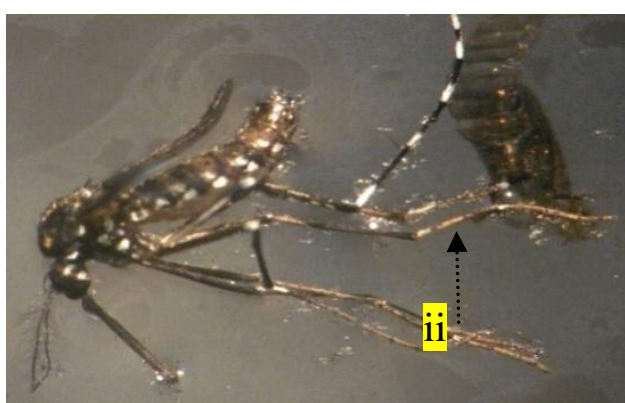

b. Aedes albopictus Mosquito

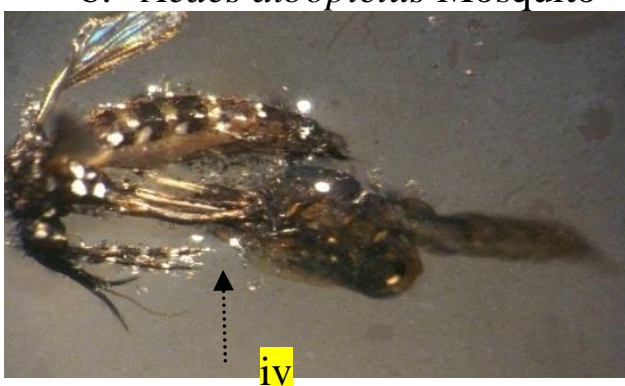

d. Aedes albopictus Mosquito 


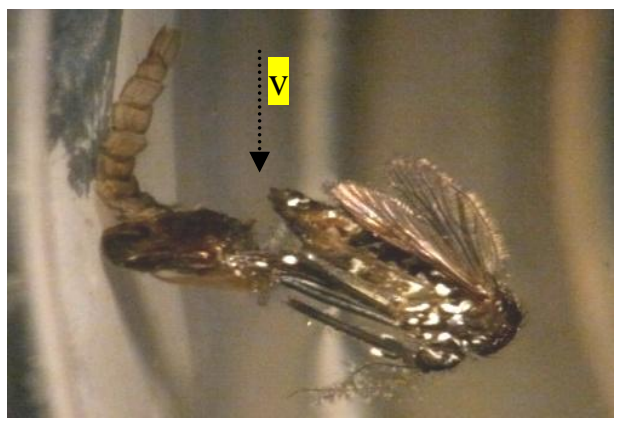

e. Aedes aegypti Mosquito

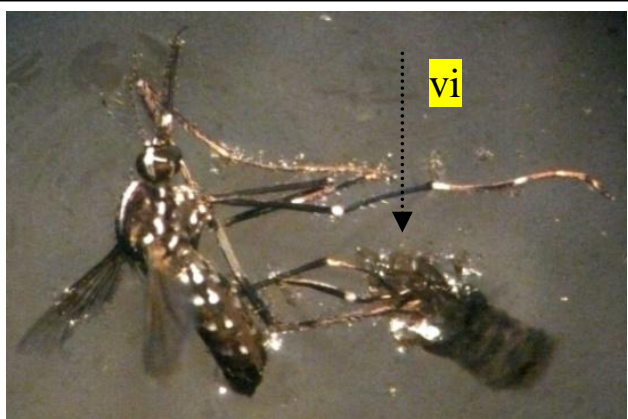

f. Aedes albopictus Mosquito

Figure 7 a-f. Adult mosquito with some parts of the body that could not get out of its pupal case

i. Wings and legs could not get out of pupal case

ii. One of the legs could not get out of pupal case

iii. Some legs could not get out of pupal case

Some Aedes aegypti and Aedes albopictus died after reaching adult stage because it could not fly so that its body was always in the water. Some could not operate because the wings could not expand either one or both of them because of the stickiness of the abdomen and thorax as shown in Figure 8.a-c. Mosquitoes could not fly and float on the surface of water due to foot abnormalities as shown in Figure 8.d-g.

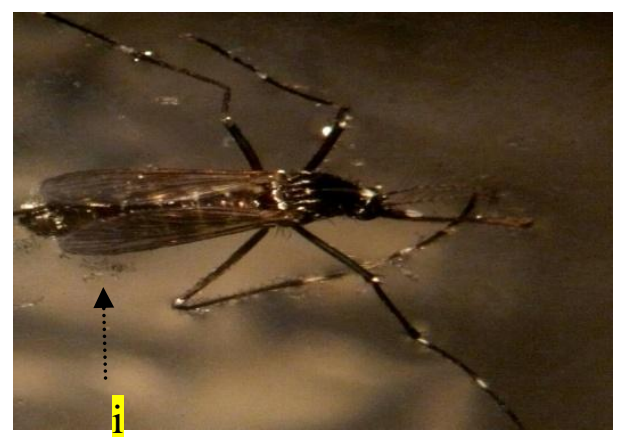

a. Aedes aegypti Mosquito

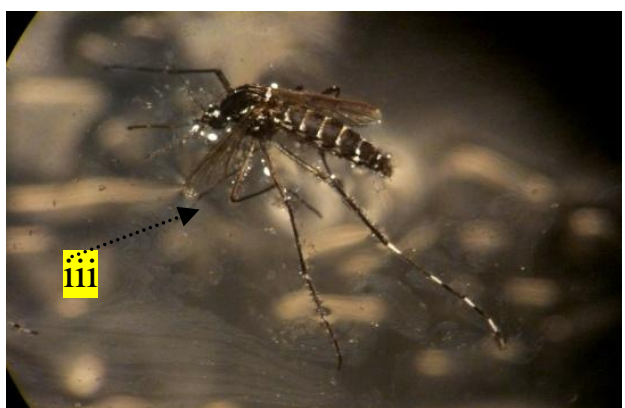

c. Aedes aegypti Mosquito

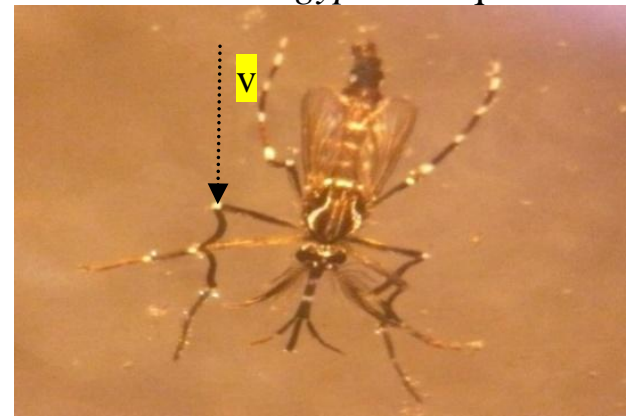

e. Aedes aegypti Mosquito

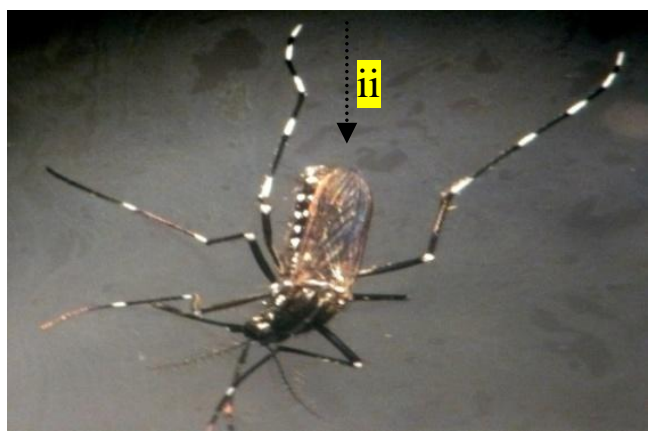

b. Aedes albopictus Mosquito

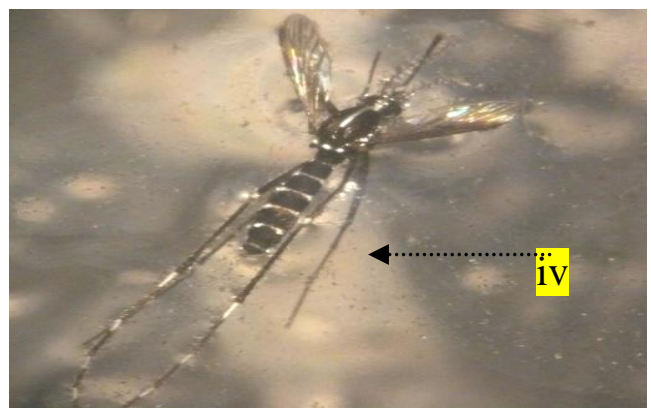

d. Aedes albopictus Mosquito

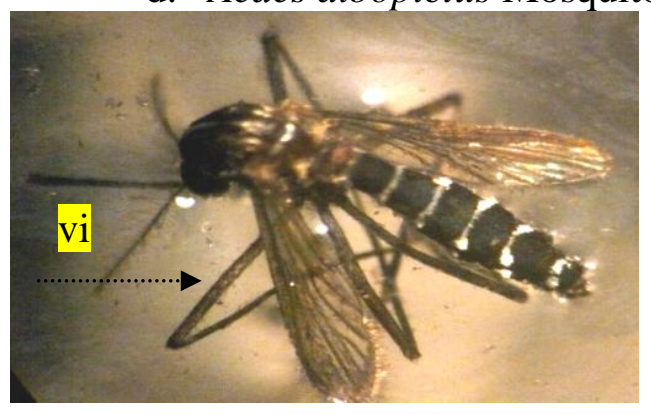

f. Aedes albopictus Mosquito 


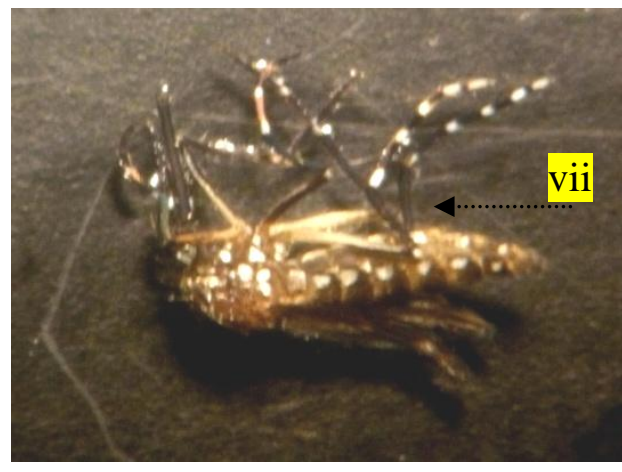

g. Aedes aegypti Mosquito

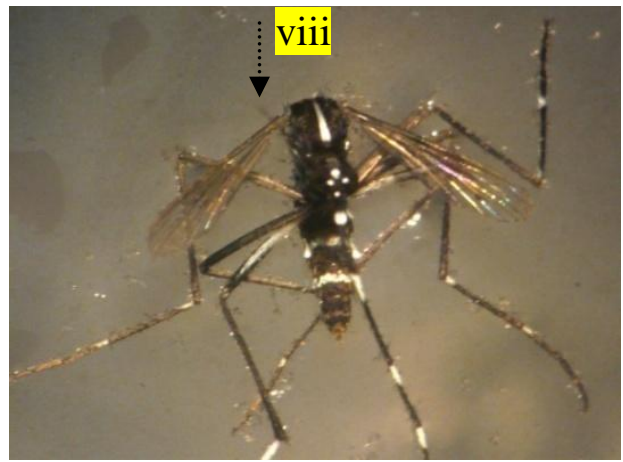

h. Aedes albopictus Mosquito

Figure 8. Adult mosquitoes could not fly due to morphological changes in the legs and wings i-ii. Wings could not expand iii-iv. The wings were imperfect, and the straight legs made it was difficult to land on the water surface

v. A pair of middle legs curved on each segment

vi. The legs were folded because the tip of the tarsus was attached to the abdomen vii. Feet were folded, and wings could not expand viii. Head to abdomen curved

\section{Discussion}

Exposure to pyriproxyfen slowed down the development of larvae to become pupae and adults. This can be seen from the observation day 9, when it was still found Aedes aegypti pupae which lived at concentration $0,05 \mathrm{ppb} ; 0.08 \mathrm{ppb}$; and $0.14 \mathrm{ppb}$ respectively $1 \% ; 2 \%$ and $1 \%$ and Aedes albopictus pupa lived at concentrations of $0.03 \mathrm{ppb} ; 0.05 \mathrm{ppb}$; and $0.23 \mathrm{ppb}$ respectively by $3 \% ; 1 \%$ and $2 \%$.

Inhibition of emergence (IE) 50 (95\% FL) of pyriproxyfen against Aedes aegypti and Aedes albopictus were $0.17 \mathrm{ppb}(0.13-0.21)$ and $0.11 \mathrm{ppb}$ (0.09-0.13) respectively, while $\mathrm{IE}_{90}$ was $0.68 \mathrm{ppb}$ (0.43-1.08) and $0.39 \mathrm{ppb}(0.26-0.57)$ respectively. The concentration of pyriproxyfen to inhibit the growth of Aedes aegypti larvae was bigger than Aedes albopictus which showed that Aedes albopictus was more susceptible than Aedes aegypti. Allegedly, this was because of the habit Aedes albopictus that usually live outside the home, so the frequency of exposure to insecticides was less. The difference between the two species was not significant because there was overlap between each confidence limit (FL95\%). The response of Aedes aegypti and Aedes albopictus to pyriproxyfen is shown by the regression line with the equation $y=2,132 x+2,404$ and $y=2,445 x+$ 2,480 which can be used to predict the concentration required to obtain the desired percentage of inhibition.

According to Sullivan (2000), pyriproxyfen given at the mosquito larvae stage will function as a juvenile hormone which then binds to the juvenile hormone receptor and will make the larvae cannot develop into an adult. The inhibition test caused many larvae to fail to become live pupae. This was because juvenile hormone disrupted the transformation of late instar larvae into pupae and subsequently matures (WHO, 2005). The failure of pupae to metamorphose into an adult mosquito will cause death in pupa stage (Gaubard, 2007).

The larvae mortality test for determination of $\mathrm{LC}_{50}$ was performed on six series of pyriproxyfen concentration on third instar larvae with the results of $\mathrm{LC}_{50}(95 \% \mathrm{FL})$ pyriproxyfen against Aedes aegypti, and Aedes albopictus were $1.63 \mathrm{ppm}(1.38-1,92)$ and 1,56ppm (1.34-1.81) respectively. The mosquito response to pyriproxyfen causing death is indicated by the regression line equation $\mathrm{y}=3.302 \mathrm{x}-0.871$ for Aedes aegypti and $\mathrm{y}=3,825 \mathrm{x}-1,626$ for Aedes albopictus which can be used to predict the 
concentration required to obtain the desired percentage of death.

The larvae mortality test was continued by determining $\mathrm{LT}_{50}$ at its $\mathrm{LC}_{50}$ concentration against two species of Aedes sp. mosquitoes. The $\mathrm{LC}_{50}$ value of pyriproxyfen against Aedes aegypti was found to be different with Aedes albopictus. The test to search for $\mathrm{LT}_{50}$ was done at the different concentrations of pyriproxyfen, and the results were also different. The $\mathrm{LT}_{50}$ values $(95 \% \mathrm{FL})$ of pyriproxyfen against Aedes aegypti and Aedes albopictus were 57,94 hours $(52,25-64,26)$ and $52,75 \mathrm{~h}(48,43-57,45)$ respectively. The mosquito response to pyriproxyfen causing death is indicated by the regression line equation $\mathrm{y}=$ $3.415 \mathrm{x}+0.881$ for Aedes aegypti and $\mathrm{y}=3,734 \mathrm{x}$ $+0,591$ for Aedes albopictus which can be used to predict the time required to obtain the desired percentage of death.

Dead larvae indicated the swelling of the thorax. The pupae showed some damages on the cuticle of the first and second abdomen so that there were some organs expelled from the body. Mature mosquitoes that showed three differences. First, perfect adult mosquitoes that can fly and no external morphological change in the legs, wings, and proboscis. Secondly, pupae that become adult mosquitoes but could not get out of the pupal case with some of its organs were still attached to the case. These mosquitoes could survive for several days, and some died. Third, an adult mosquito that could come out of the pupal case but could not fly because there were legs that could not support the body, so it fell in the water. Some were alive when they were removed from the water, but a day later died. It was suspected because of the weak physical, and it could not suck the juice of food in the form of sugar water so that there was a decrease in endurance. Further, it was also found an adult mosquito that could not flap its wings because it was sticky on the thorax or abdomen, so it could not fly. Percentage of those that cannot fly was more significant than the ones that could not get out of the case. According to Tunaz and Uygun (2004), the use of IGR leads to various abnormalities in insects thus decreasing its ability to survive. Siddal (1976) also says a similar thing that IGR caused a variety of defects that disrupt the life of insects although it is not very toxic.

\section{Conclusion}

Based on the results of the research, it can be concluded as follows:

1. Pyriproxyfen could inhibit the growth of Aedes aegypti larvae with $\mathrm{IE}_{50}$ of $0.17 \mathrm{ppb}$ and $\mathrm{IE}_{90}$ of $0.68 \mathrm{ppb}$ and inhibit the growth of Aedes albopictus larvae with $\mathrm{IE}_{50}$ of $0.11 \mathrm{ppb}$ and $\mathrm{IE}_{90}$ of $0.39 \mathrm{ppb}$.

2. Pyriproxyfen caused death after 48 hours of exposure to Aedes aegypti larvae at $\mathrm{LC}_{50}$ of $1.63 \mathrm{ppm}$ and $\mathrm{LT}_{50}$ of 57.94 hours and on Aedes albopictus larvae at $\mathrm{LC}_{50}$ of $1.56 \mathrm{ppm}$ and $\mathrm{LT}_{50}$ of 52.75 hours.

3. External morphological changes occurred in larvae, pupae, and adult mosquitoes, especially on the feet. The wings did not experience morphological changes except the adhesions happened in the abdomen. Proboscis did not change on both Aedes aegypti and Aedes albopictus larvae.

\section{References}

1. Ali, A., Nayar, J.K., De Xue, R., 1995, Comparative Toxicity of Selected Larvicides and Insect Growth Regulators to A Florida Laboratory Population of Aedes albopictus, Journal of the American Mosquito Control Association, 11(1),7276.

2. Anonim, 2007, Pyriproxyfen(200), http://www.fao

org/ag/AGP/AGPP/pesticid /JMPR / /99 eva/25 pyriproxyfen.pdf download tanggal 8 Juli 2007.

3. Belding, D.L, 1952, Textbook of Clinical Parasitology, Appleton Century Crofts, Inc, New York, 745.

4. Chism, B.D, Apperson, C.S., Horizontal transfer of the Insect Growth Regulator pyriproxyfen to larval microcosms by 
Gravid Aedes albopictus and Ochloretatus triseriatus Mosquitoes in the Laboratory, Medical and Veterinary Entomology(2003)17:211-220.

5. Cutwa M., O’Meara, G. F., 2006, Photographic Guide to Common Mosquitoes of Florida, Florida Medical Entomology Laboratory, University of Florida, Florida.

6. Depkes, 2007, Modul Pelatihan Bagi Pengelola Program Pengendalian Penyakit Demam Berdarah Dengue di Indonesia, Ditjen PP PL Depkes, Jakarta.

7. Djakaria, S., 1998, Pendahuluan Entomologi dan Vektor Penyakit Virus, Riketsia, Spiroketa, dan Bakteri dalam Parasitologi Kedokteran editor Gandahusada S., Ilahude H. D., Pribadi W., Edisi ketiga, Fakultas Kedokteran Universitas Indonesia, Jakarta, 213.

8. Dinkes Kota Tangerang, 2015, Arsip Data DBD di Kota Tangerang.

9. Finney, D.J., 1971, Probit Analysis, Third edition, At the University Press, Cambridge.

10. Gaubard, J., 2007, Juvenile Hormone Binding Proteins Importance in the $\mathrm{JH}$ action, Introductory paper no 168, Lund University http:/www.kem.ekol. lu.se/introyohann.

11. Hoedojo, 1998, Morfologi, Daur Hidup dan perilaku nyamuk dalam Parasitologi Kedokteran editor Gandahusada S., Ilahude H. D., Pribadi W., Edisi ketiga, Fakultas Kedokteran Universitas Indonesia, Jakarta, 221-224.

12. Hoedojo, Zulhasriel, 1998, Pengendalian Vektor dalam Parasitologi Kedokteran editor Gandahusada S., Ilahude H. D., Pribadi W., Edisi ketiga, Fakultas Kedokteran Universitas Indonesia, Jakarta, 244-246.

13. Kesumawati Hadi,U., Koesharto, 2006, Nyamuk dalam Hama Permukiman Indonesia: Pengenalan, Biologi dan
Pengendalian editor Sigit, S.H, Kesumawati Hadi, U., Institut Pertanian Bogor, Bogor, 23-48

14. Kusriastuti, R., 2007, Kebijaksanaan Penanggulangan Demam Berdarah Dengue dalam Simposium Nasional Demam Berdarah Dengue, aspek Biologi Molekuler, Patogenesis, Manajemen dan Pencegahan Kejadian Luar Biasa, Pusat Studi Bioteknologi, Universitas Gadjah Mada, Yogyakarta, 16 Mei 2007.

15. Mardihusodo, S.J., 2004, Cara-cara Inovatif Pengamatan dan Pengendalian Nyamuk Vektor, DBD, Pusat Kedokteran Tropis, UGM, Yogyakarta.

16. Munif, Amrul, 1997, Pengaruh Residu Pyriproxyfen $0,5 \%$ terhadap Larva Aedes aegypti Pada Berbagai Simulasi Wadah Air, Cermin Dunia Kedokteran Nomor 119, Jakarta.

17. Ponlawat, A., Scott, J.G., Harrington, L.G., 2005, Insecticide Susceptibility of Aedes aegypti and Aedes albopictus across Thailand, J. Medical Entomology, 42(\%),821-825.

18. Rozendaal, 1997, Vector Control; Methods for Use by Individuals and Communities, WHO, Geneva, 38-39,123.

19. Service, M. W., 1996, Medical Entomology for Students, First edition, Chapman\&Hall, London.

20. Siddal, J.B., 1976, Insect Growth Regulators and Insect Control: A. Critical Appraisal, Environmental Health Persp., Vol 14, 119-126.

21. Sihuincha, M., Perea, E.Z., Rioz, W.O., Stancil, J.D., 2005, Potential Use of Pyriproxyfen for Control of Aedes aegypti (Diptera: Culicidae) in Iquitos, Peru, J. Med.Entomol, 42(4), 620-630.

22. Sullivan, J., 2000, Environmental Fate of Pyriproxyfen, Environmental Monitoring and Pest Management Branch, Sacramento. 
23. Sutaryo, 2004, Dengue, Medika Fakultas Kedokteran UGM, Yogyakarta.

24. Sutomo, S., 2003, Rencana Strategi Pencegahan \&Pemberantasan Demam Dengue/Demam Berdarah Dengue 20042006, Ditjen P2M-PL Depkes R.I., Jakarta

25. Tunaz, H., Uygun, N., 2004, Insect Growth Regulators for Insect Pest Control, Turk J. Agric For 28(2004), 377387.

26. Waris, L., 2005, Pengaruh pyriproxyfen terhadap vektor malaria Anopheles subpictus grassi asal Pulau Kalimantan dalam Seminar Regional Sulawesi, Palu, 29 September 2005.

27. WHO, 1995, Report of the Informal Consultation on Aircraft Disinsection, Geneva.

28. WHO, 2001, Report of The Fourth Whopes, Working Group Meeting, Review of IR3535; KBR3023;(RS)-Methoprene 20\%EC, Pyriproxyfen 0,5\% GR, and Lambda-Cyhalothrin 2,5\%CS, WHO/CDC/WHOPES, Geneva, 50.

29. WHO, 2005, Guidelines For Laboratory and Field Testing of Mosquito Larvicides, WHO Communicable Disease Control, Prevention, and Eradication, WHOPES, Geneva

30. WHO, 2006, Pyriproxyfen, WHO specifications and Evaluations for Public Health Pesticides, Geneva.

31. Widyana, 1997, Pengaruh Penerapan Metode Pengendalian Vektor Terhadap Populasi Pradewasa Aedes aegypti di Kecamatan Kasihan Bantul, Tesis, UGM, Yogyakarta. 